\title{
Adsorption of Cadmium (II) and Chromium (VI) from Aqueous Solution by Waste Marigold Flowers
}

\author{
Monoj K. Mondal"1, Garima Mishra ${ }^{2}$, Pradeep Kumar ${ }^{3}$ \\ ${ }^{1}$ Department of Chemical Engineering and Technology, Indian Institute of Technology (Banaras Hindu \\ University), Varanasi-221005, Uttar Pradesh, India \\ e-mail: mkmondal13@yahoo.com \\ ${ }^{2}$ Department of Chemical Engineering and Technology, Indian Institute of Technology (Banaras Hindu \\ University), Varanasi-221005, Uttar Pradesh, India \\ e-mail: garima.it.bhu@gmail.com \\ ${ }^{3}$ Department of Chemical Engineering and Technology, Indian Institute of Technology (Banaras Hindu \\ University), Varanasi-221005, Uttar Pradesh, India \\ e-mail: pkumar.che@itbhu.ac.in
}

Cite as: Mondal, M. K., Mishra, G., Kumar, P., Adsorption of Cadmium (II) and Chromium (VI) from Aqueous Solution by Waste Marigold Flowers, J. sustain. dev. energy water environ. syst., 3(4), pp 405-415, 2015, DOI: http://dx.doi.org/10.13044/j.sdewes.2015.03.0030

\begin{abstract}
In this work, waste marigold flowers from Temple were used as adsorbent to remove cadmium (II) and chromium (VI) ions from aqueous solutions. Influences of initial heavy metal concentrations, contact time, adsorbent dose, temperature and initial $\mathrm{pH}$ on removal of cadmium (II) and chromium (VI) ions were studied under batch mode of operation. Both the adsorption process of cadmium (II) and chromium (VI) followed pseudo-second order kinetics. Adsorption isotherm parameters of cadmium (II) and chromium (VI) on dried marigold flower were determined using Langmuir and Freundlich models. Thermodynamic parameters depicted that the process was spontaneous and exothermic under experimental conditions. The maximum removal efficiency of cadmium (II) was obtained as $83 \%$ at contact time $75 \mathrm{~min}$ and $\mathrm{pH} 5$. The maximum removal efficiency of chromium (VI) was found as $96 \%$ at contact time 105 min and $\mathrm{pH}$ 3. Dried marigold flower showed active reusability characteristics upto three consecutive adsorption-desorption cycles.
\end{abstract}

\section{KEYWORDS}

Adsorption, Cd(II) and Cr(VI), Kinetics, Isotherms, Marigold flower.

\section{INTRODUCTION}

Heavy metal contamination of water through the discharge of industrial wastewater is a growing environmental issue worldwide. The most common heavy metal contaminating industries are metal plating, mining operations, battery manufacturing, paints and pigments, ammunition, ceramic and glass industries. The wastewater from these industries commonly contain toxic heavy metals like $\mathrm{Cd}$ (II), $\mathrm{Pb}$ (II), $\mathrm{Cu}$ (II), $\mathrm{Ni}$ (II), and Cr (VI) [1]. Industrialization moves so rapid that the discharge of heavy metals into the environment increases accordingly [2]. Numbers of treatment methods like ion exchange [3], precipitation, filtration, oxidation-reduction, membrane separation, and adsorption $[3,4]$ are known for separation and removal of metallic species from aqueous solutions and wastewaters. It has been reported that application of these methods is limited due to high operational costs or insufficient removal efficiencies to meet the

\footnotetext{
* Corresponding author
} 
environmental requirements. The most familiar metals refer to heavy metals having density more than or equal to $6.0 \mathrm{~g} / \mathrm{mL}$ such as:

- Cadmium $(8.65 \mathrm{~g} / \mathrm{mL})$;

- Chromium $(7.19 \mathrm{~g} / \mathrm{mL})$;

- Cobalt $(8.90 \mathrm{~g} / \mathrm{mL})$;

- Copper $(8.95 \mathrm{~g} / \mathrm{mL})$;

- $\quad$ Lead $(11.34 \mathrm{~g} / \mathrm{mL})$;

- Mercury $(13.53 \mathrm{~g} / \mathrm{mL})$;

- $\quad$ Nickel $(8.91 \mathrm{~g} / \mathrm{mL})$;

- Zinc $(7.14 \mathrm{~g} / \mathrm{mL})$.

The hostile effects of cadmium on human lives include high blood pressure, kidney damage, destruction of testicular tissues and red blood cells [5]. Chromium occurs in two stable oxidation states, $\mathrm{Cr}$ (III) and $\mathrm{Cr}$ (VI), in nature. The $\mathrm{Cr}$ (III) is relatively innocuous, but $\mathrm{Cr}$ (VI) is toxic, carcinogenic and mutagenic in nature, and highly mobile in soil and aquatic system [6].

Several investigations have been made in this area utilizing number of materials like:

- Sunflower stalks [7];

- Almond-shell carbon [8];

- Sugarcane baggase [9];

- Oak saw dust [10];

- Wheat bran [11];

- Maize bran [12], etc.

Varanasi is a city of temples in India and more than 1,000,000 pilgrims visit the city each year. Marigold flowers are very cheap and easily available around the year. Most of the poor people generally use the garlands of marigold flowers to pray and bow their heads to Lord Shiva. Hence, a lot of flower waste is generated daily. Present study deals with series of batch adsorption experiments to assess the potentiality of dried marigold flower for removal of $\mathrm{Cr}$ (VI) and $\mathrm{Cd}$ (II) from aqueous solutions. The adsorption kinetics, isotherm models and thermodynamic parameters were determined to understand the mechanism and nature of adsorption process.

\section{MATERIALS AND METHODS}

\section{Preparation of adsorbent}

The marigold flower wastes were collected from Lord Shiva temple, Varanasi in the University campus. It was washed with sufficient amount of distilled water to remove water soluble substances and surface adhered impurities. The washed marigold flower wastes were then dried at $100{ }^{\circ} \mathrm{C}$ in hot air oven for $12 \mathrm{~h}$, then ground with the help of grinder and stored in air tight plastic containers.

\section{Reagents and equipments}

All chemicals and reagents used were of the analytical reagent grade and obtained from E. Merck, India. The $\mathrm{pH}$ of the solution was measured by using $\mathrm{pH}$ meter (LI 120, Elico, India). A shaking speed incubator (Model NSW-133, Calton, and New Delhi, India) was used for shaking the content to execute batch adsorption experiments. An oven (S.M. Scientific Instruments Pvt. Ltd., New Delhi) was used for drying the adsorbent. To examine the mineral identification of adsorbent, X-Ray Diffraction (XRD) studies were done. The XRD data was obtained by $18 \mathrm{~kW}$ rotating anode based powder diffractometer (Rigaku, Japan) fitted with a curved crystal monochromator in the diffracted beam operating at $40 \mathrm{kV}$ and $150 \mathrm{~mA}$. Nature of bonding was visualized by 
FTIR JASCO spectrophotometer (Model-5300). The particle size of the adsorbent was determined by sieve analysis. The concentration of Cd (II) and $\mathrm{Cr}$ (VI) before and after adsorption was measured using a UV-Visible spectrophotometer (SL 159, Elico, India).

\section{Preparation of Cr (VI) and Cd (II) standards}

The stock solution of $\mathrm{Cd}$ (II) $(1,000 \mathrm{mg} / \mathrm{L})$ and $\mathrm{Cr}$ (VI) $(1,000 \mathrm{mg} / \mathrm{L})$ were prepared by dissolving $\mathrm{AR}$ grade $\mathrm{Cd}\left(\mathrm{NO}_{3}\right)_{2} \cdot 4 \mathrm{H}_{2} \mathrm{O}$ and $\mathrm{K}_{2} \mathrm{Cr}_{2} \mathrm{O}_{7}$ in deionized water. The stock solutions were further diluted with deionized water to get desired concentration of $\mathrm{Cd}$ (II) and $\mathrm{Cr}(\mathrm{VI})$ for experimentations.

\section{Adsorption experiments}

Adsorption experiments were conducted in a series of glass stoppered conical flasks by agitating a weighed amount $(0.8 \mathrm{~g}$ for $\mathrm{Cr}$ (VI) and $0.2 \mathrm{~g}$ for $\mathrm{Cd}$ (II)) of adsorbent with $100 \mathrm{~mL}$ aqueous solution of $\mathrm{Cr}$ (VI) or $\mathrm{Cd}$ (II). The solution $\mathrm{pH}$ was adjusted to the desired value by adding $0.1 \mathrm{M} \mathrm{HCl}$ or $0.1 \mathrm{M} \mathrm{NaOH}$. The flasks were shaken at $30{ }^{\circ} \mathrm{C}$ using a mechanical shaker for a desirable time. At the end of pre-determined time intervals the flasks were withdrawn from shaker and supernatant liquid after filtering the contents was analysed spectrophotometrically to find out remaining heavy metal ion concentration. The percent removal of Cd (II) or $\mathrm{Cr}$ (VI) was calculated for each run by following eq. (1):

$$
\% \text { Removal }=\frac{\left(C_{0}-C_{t}\right)}{C_{0}} \times 100
$$

Adsorption capacities of the dried marigold flower for Cd (II) or Cr (VI) were calculated using the equation as given below:

$$
q_{e}=\frac{\left(C_{0}-C_{t}\right) V}{M}
$$

where:

- $q_{e}$ is adsorption capacity for heavy metal removal per unit mass of adsorbent $[\mathrm{mg} / \mathrm{g}]$;

- $M$ is mass of adsorbent $[\mathrm{g}]$;

- $V$ is volume of sample [L];

- $C_{0}$ is the initial concentration of heavy metal in the test solution $[\mathrm{mg} / \mathrm{L}]$;

- $C_{t}$ is concentration at any time $t[\mathrm{mg} / \mathrm{L}]$;

- and $C_{e}$ is the final equilibrium concentration of heavy metal in solution $[\mathrm{mg} / \mathrm{L}]$.

All the experiments were accomplished in duplicate with uncertainty of $\pm 0.1 \%$ for the measured data, and the average values were reported.

\section{RESULTS AND DISCUSSION}

\section{Characterization of the adsorbent}

To understand the mechanism of adsorption of heavy metal onto adsorbent, it is necessary to determine point of zero charge of the adsorbent $\left(\mathrm{pH}_{\mathrm{zpc}}\right)$. The specific adsorption of cation shifts $\mathrm{pH}_{\mathrm{zpc}}$ towards lower value, whereas the specific adsorption of anions shifts $\mathrm{pH}_{\mathrm{zpc}}$ towards higher value. The $\mathrm{pH}_{\mathrm{zpc}}$ of dried marigold flower was found as 4.12. XRD study of dried marigold flower was performed by powder diffractometer (Rigaku, Japan) fitted with a curved crystal monochromator in the diffracted beam 
operating at $40 \mathrm{kV}$ and $150 \mathrm{~mA}$. The data were collected in the angular (2Ө) range from 20 to 120 degrees with a step size of 0.02 degrees at a rate of 2 degrees per minute. The recorded XRD profiles were compared with standard profiles by the help of JCPDF files and the compounds such as $\mathrm{SiO}_{2}, \mathrm{MgO}, \mathrm{CaO}$ and $\mathrm{Al}_{2} \mathrm{O}_{3}$ were identified in the sample. Dried marigold flower was found to contain carbon and silica based materials that bound the heavy metal ions from aqueous solution.

The functional group is one of the keys to understand the mechanism of heavy metal binding on dried marigold flower. Fourier Transform Infrared Spectroscopy (FTIR) of adsorbent for identifying the functional groups in 4,000-400 $\mathrm{cm}^{-1}$ range was shown in Figure 1 . The strong absorption band at $3,986-3,710 \mathrm{~cm}^{-1}$ was stretching vibrations of surface hydroxyl groups. The band $2,963 \mathrm{~cm}^{-1}$ was assigned to symmetric vibration of C-H group especially alkenes. The strong bands at 2,348 and $2,345 \mathrm{~cm}^{-1}$ were stretching vibrations of $\mathrm{N}-\mathrm{H}$ and $\mathrm{C}=\mathrm{O}$ groups probably due to amines and ketones. The bands at 1,723 and $1,728 \mathrm{~cm}^{-1}$ were, respectively, attributed to carbonyl groups (mainly aldehydes and ketones) conjugated not to aromatic rings. The bands at 1,029 and $1,034 \mathrm{~cm}^{-1}$ are stretching vibration of $\mathrm{C}-\mathrm{O}-\mathrm{C}$ and $\mathrm{O}-\mathrm{H}$ of polysaccharides. The bands at 1,526 and 1,528 $\mathrm{cm}^{-1}$ were an identification of $\mathrm{COO}$ and $\mathrm{C}=\mathrm{O}$ groups. The $\mathrm{N}-\mathrm{H}$ stretching appears at $3,437 \mathrm{~cm}^{-1}$. The peaks at 631,604 and $527 \mathrm{~cm}^{-1}$ were assigned for bending modes of aromatic compounds. FTIR spectrum of dried marigold flower showed that it was composed of polymeric $\mathrm{OH}$ group, $\mathrm{C}-\mathrm{H}$ and $\mathrm{COO}$ groups of polysaccharides. All these groups were known to have strong affinity of heavy metal adsorption.

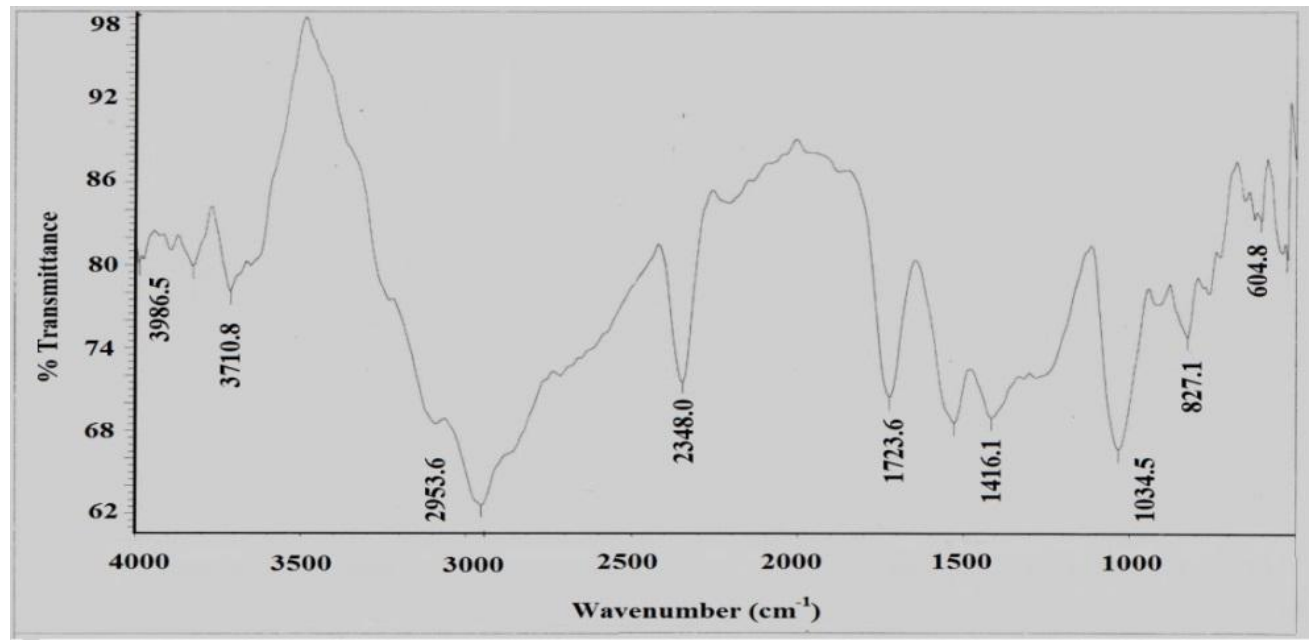

Figure 1. FTIR plot of dried marigold flower

\section{Effect of initial concentration and contact time}

Figure 2 showed the effect of contact time on batch adsorption of $\mathrm{Cd}$ (II) and $\mathrm{Cr}$ (VI) at $30{ }^{\circ} \mathrm{C}$. Initially, the percent removal increased slowly with time and then it reached a maximum value in approximately $75 \mathrm{~min}$ for $\mathrm{Cd}$ (II) and $105 \mathrm{~min}$ for $\mathrm{Cr}$ (VI), respectively. After that it decreased gradually to reach the equilibrium value. The maximum removal of $\mathrm{Cd}$ (II) and $\mathrm{Cr}$ (VI) was found as 78 and $92 \%$, respectively at initial concentration of $10 \mathrm{mg} / \mathrm{L}$. The atomic radius of $\mathrm{Cr}(\mathrm{VI})(1.28 \AA)$ is less than that of $\mathrm{Cd}$ (II) $(1.51 \AA)$. Higher the atomic radius of metal, the lower is its diffusive mobility in an aqueous medium. Therefore, the diffusive mobility of Cd (II) from bulk of the liquid to the surface of adsorbent is slower as compared to $\mathrm{Cr}$ (VI) in aqueous solutions which may lead to the lower adsorption of Cd (II) than Cr (VI) by the adsorbent. For both Cd (II) and $\mathrm{Cr}$ (VI), the percent removal decreases with increase in initial concentration of heavy metal ions. The variation in percent removal of $\mathrm{Cd}$ (II) and $\mathrm{Cr}$ (VI) ions may be due to the 
fact that initially all sites on the surface of adsorbent were empty and the solute concentration gradient was relatively high for increased initial metal ion concentration [13]. Consequently in the latter stage percent removal decreased with increase in time, depending on the less number of vacant sites available which may be difficult to occupy due to repulsive forces between solute molecules of the adsorbent surface and bulk of the liquid phase [14].
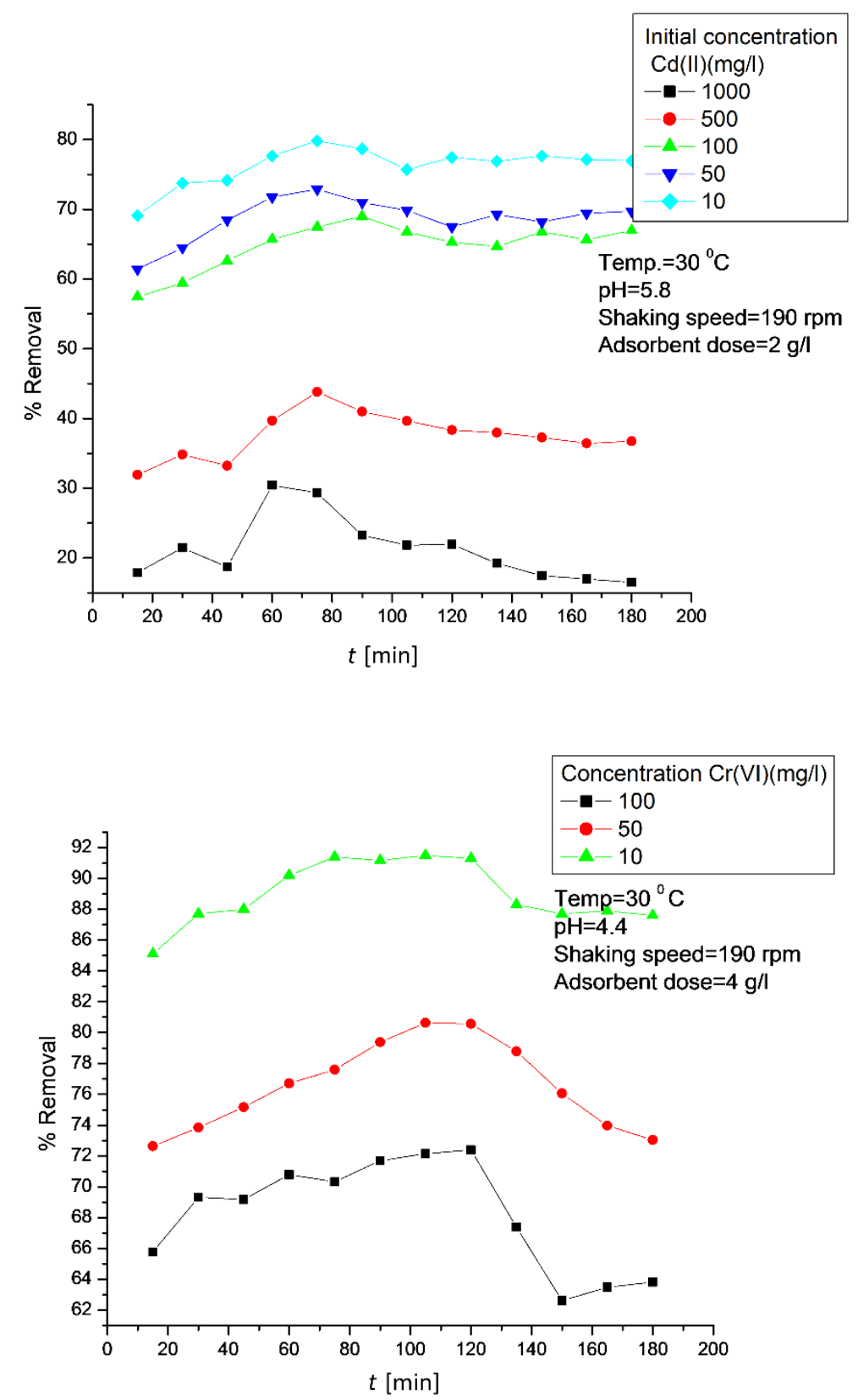

Figure 2. Effect of contact time on removal of Cd (II) and Cr (VI) ions

\section{Effect of adsorbent dose}

To achieve maximum percent removal of $\mathrm{Cd}$ (II) and $\mathrm{Cr}$ (VI) ions, adsorbent dose was varied from 0.5 to $10 \mathrm{mg} / \mathrm{L}$ for Cd (II) and 2 to $10 \mathrm{mg} / \mathrm{L}$ for $\mathrm{Cr}$ (VI). It was noticed that adsorbent doses of $2 \mathrm{~g} / \mathrm{L}$ and $8 \mathrm{~g} / \mathrm{L}$ were enough for maximum removal of $\mathrm{Cd}$ (II) and $\mathrm{Cr}$ (VI) ions, respectively (Figure 3). At initial stage, increase in percent removal of both heavy metal ions with increase in adsorbent dose was due to the availability of more and 
more adsorbent surfaces for adsorption. It was also seen from Figure 3 that a further increase in adsorbent dose (beyond $8 \mathrm{~g} / \mathrm{L}$ ) did not affect the adsorption greatly for $\mathrm{Cr}$ (VI) ions but for $\mathrm{Cd}$ (II) ions the decrease in adsorption after maximum removal with increase in adsorbent dose was due to the adsorption sites remained unsaturated during the adsorption reaction. There may be the larger resistance for Cd (II) ions to penetrate from surface to the interior of the adsorbent indicating the decrease in adsorption later on with adsorbent dose [15].
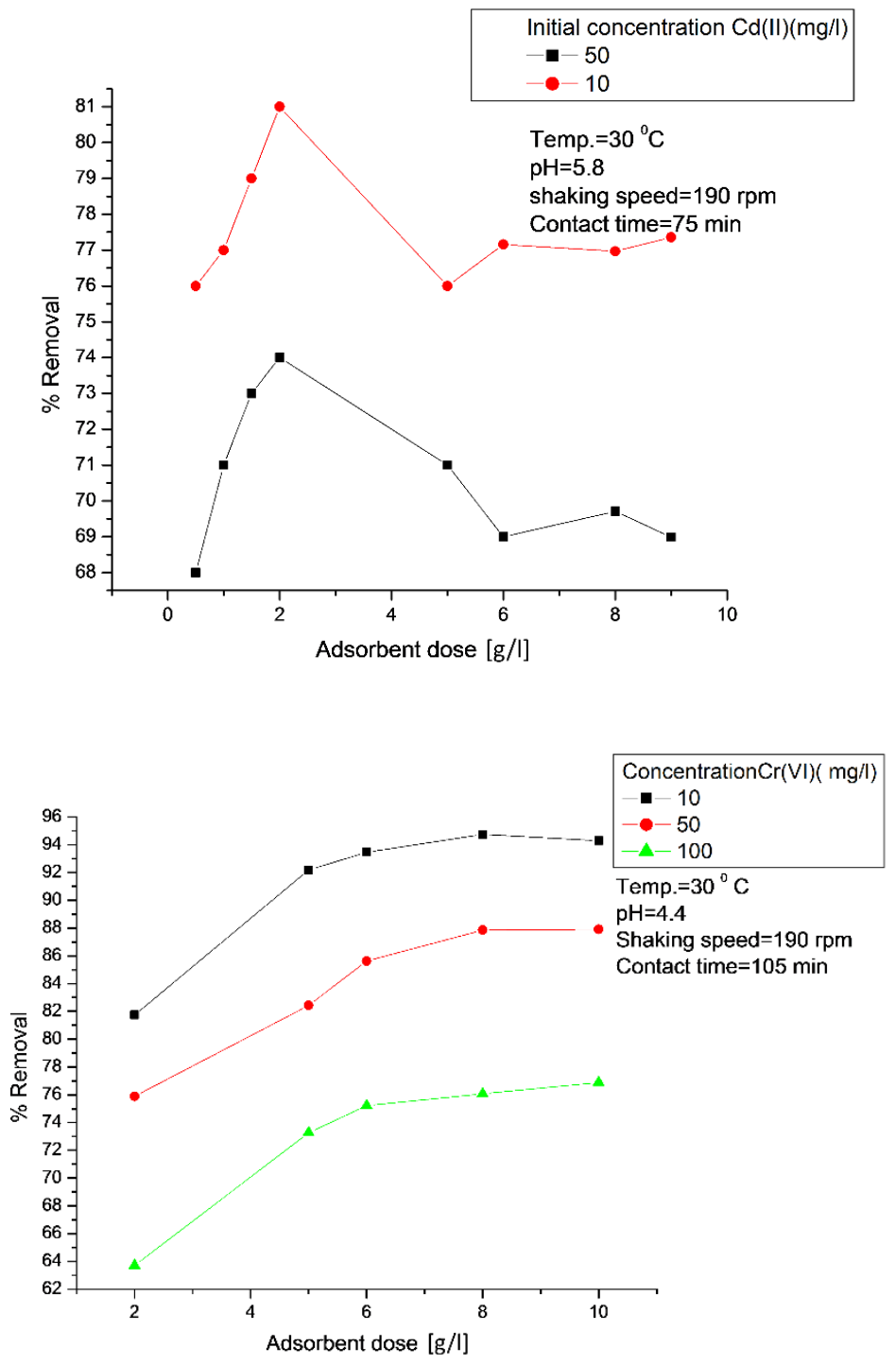

Figure 3. Effect of adsorbent dose on removal of Cd (II) and Cr (VI) ions

\section{Effect of pH}

The $\mathrm{pH}$ is an important parameter which affects metal chemistry depending on surface charge of the heavy metal binding sites onto the adsorbent [14]. To see the effect of $\mathrm{pH}$ on removal of $\mathrm{Cd}$ (II) and $\mathrm{Cr}$ (VI), the initial $\mathrm{pH}$ was changed from 1 to 9 and the results are shown in Figure 4. It was observed that percent removal increases as the initial $\mathrm{pH}$ was increased and attained a maximum value at a particular $\mathrm{pH}$. After that, it was found to decrease in both $\mathrm{Cd}$ (II) and $\mathrm{Cr}$ (VI) adsorption. The maximum removal of $\mathrm{Cd}$ (II) and $\mathrm{Cr}$ (VI) were achieved at $\mathrm{pH} 3$ and 5, respectively. The decrease of percent removal at higher $\mathrm{pH}$ may be attributed to the hydroxide formation of $\mathrm{Cd}$ (II) and $\mathrm{Cr}$ (VI) [16]. 


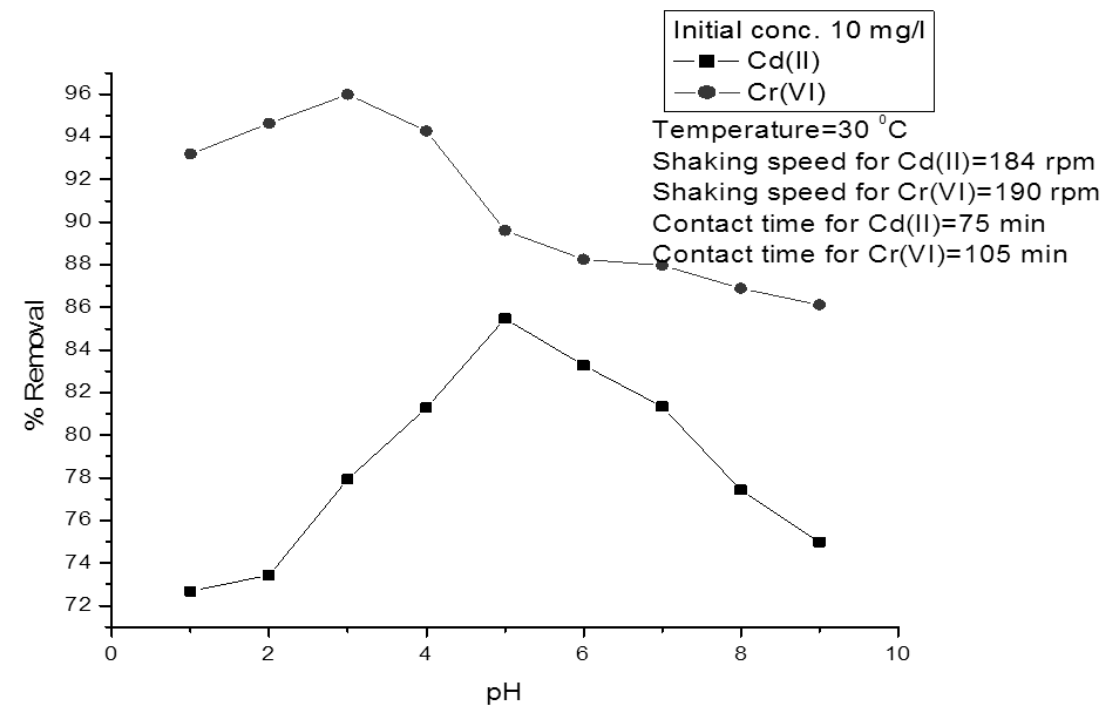

Figure 4. Effect of $\mathrm{pH}$ on percent removal of $\mathrm{Cd}$ (II) and $\mathrm{Cr}$ (VI) ions

\section{Effect of temperature}

The effect of temperature on percent removal of Cd (II) and Cr (VI) was investigated over the temperature range of 30 to $50{ }^{\circ} \mathrm{C}$. The results were shown in Figure 5. It was evident from Figure 5 that the maximum adsorption was observed at $30{ }^{\circ} \mathrm{C}$ for both $\mathrm{Cd}$ (II) and $\mathrm{Cr}$ (VI) ions and it was decreased with increasing temperature. The increase in adsorption with decreasing temperature showed exothermic nature of adsorption process [13].

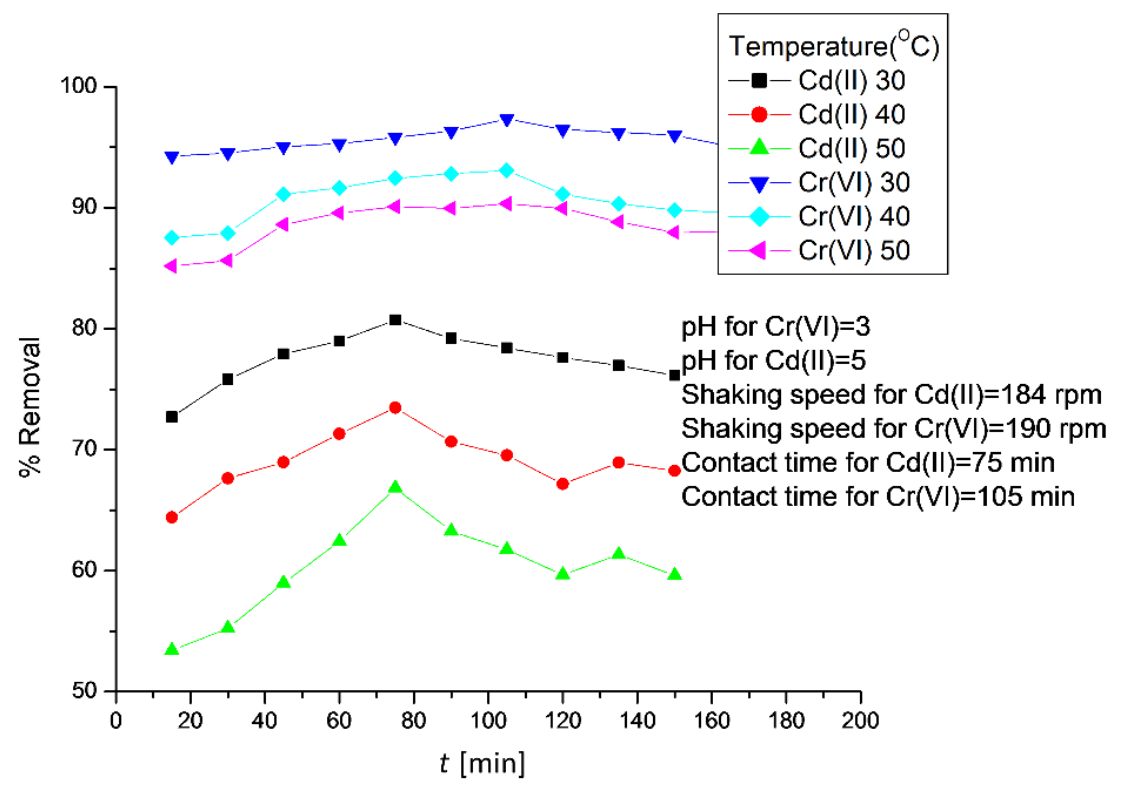

Figure 5. Effect of temperature on percent removal of Cd (II) and $\mathrm{Cr}$ (VI) ions

\section{Adsorption isotherms for Cd (II) and Cr (VI)}

In this study, equilibrium data were analyzed by employing well known Langmuir and Freundlich adsorption isotherms [16] which are as follows, respectively:

$$
\frac{1}{q_{e}}=\frac{1}{Q_{\mathrm{o}}}+\frac{C_{e}}{b Q_{\mathrm{o}}}
$$




$$
\ln q_{e}=\ln K_{F}+\frac{\ln C_{e}}{n}
$$

where:

- $q_{e}$ is amount adsorbed $[\mathrm{mg} / \mathrm{g}]$;

- $C_{e}$ is the equilibrium concentration of the adsorbate $[\mathrm{mg} / \mathrm{L}]$;

- $Q_{0}$ and $b$ are the Langmuir constants related to maximum adsorption capacity and energy of adsorption, respectively;

- $\quad K_{F}$ and $n$ are Freundlich constants related to adsorption capacity and adsorption intensity, respectively.

The regression values of all isotherms constants were given in Table 1. Freundlich isotherm for adsorption of $\mathrm{Cd}$ (II) and $\mathrm{Cr}$ (VI) was fitted better than the Langmuir isotherm, which is evident from value of regression coefficient $\left(R^{2}\right)$.

Table 1. Langmuir and Freundlich constants for adsorption of Cd (II) and $\mathrm{Cr}$ (VI)

\begin{tabular}{ccccccc}
\hline Adsorbates & \multicolumn{3}{c}{ Langmuir parameters } & \multicolumn{3}{c}{ Freundlich parameters } \\
\hline & $Q_{\mathrm{o}}[\mathrm{mg} / \mathrm{g}]$ & $b[1 / \mathrm{mg}]$ & $R^{2}$ & $K_{F}$ & $n$ & $R^{2}$ \\
\cline { 2 - 7 } $\mathrm{Cd}(\mathrm{II})$ & 55.56 & 0.014 & 0.968 & 1.33 & 1.420 & 0.978 \\
$\mathrm{Cr}(\mathrm{VI})$ & 11.11 & 0.140 & 0.989 & 1.11 & 1.686 & 0.999 \\
\hline
\end{tabular}

\section{Adsorption kinetics}

The prediction of adsorption kinetics is most important factor as it describes the solute uptake rate which intern controls the residence time of solute uptake at the solid liquid interface $[17,18]$. In order to determine the adsorption kinetics for $\mathrm{Cd}$ (II) and $\mathrm{Cr}$ (VI) removal, Lagergren kinetic model was tested. The pseudo first order model proposed by Lagergren can be expressed as [7]:

$$
\log \left(q_{e}-q_{t}\right)=\log q_{e}-\frac{k_{1} t}{2.303}
$$

where:

- $q_{e}$ is the amount of adsorbed $[\mathrm{mg} / \mathrm{g}]$ at equilibrium;

- $q_{t}$ is the amount adsorbed $[\mathrm{mg} / \mathrm{g}]$ at time $t$;

- and $k_{1}$ the adsorbent rate constant $\left[\mathrm{min}^{-1}\right]$.

The values of $k_{1}$ were given in Table 2 . The simplified form of pseudo second order model can be written as [14]:

$$
\frac{t}{q_{t}}=\frac{1}{k_{2} \times q_{e}^{2}}+\frac{t}{q_{e}}
$$

where $k_{2}$ is the adsorption rate constant (g/mg.min). The values of $k_{2}$ were given in Table 2 . The values of correlation coefficient $\left(R^{2}\right)$ confirmed the better applicability of pseudo second- order model as compared to pseudo first order rate equation for the adsorption of $\mathrm{Cd}$ (II) and $\mathrm{Cr}$ (VI). The intraparticle diffusion varies with square root of time is also attempted using the following expression [14]:

$$
q_{t}=k_{i d} t^{1 / 2}
$$


where $k_{i d}\left(\mathrm{mg} / \mathrm{g} \min ^{1 / 2}\right)$ is the rate constant of intraparticle diffusion. The values of $k_{i d}$ were given in Table 2. The $\mathrm{Cd}$ (II) and $\mathrm{Cr}$ (VI) adsorption onto dried marigold flower indicated that some degree of boundary layer may also control the adsorption process and intraparticle diffusion may not be the sole rate- limiting step.

Table 2. Kinetic parameters of Cd (II) and Cr (VI) adsorption onto waste marigold

\begin{tabular}{ccccccc}
\hline Adsorbates & \multicolumn{3}{c}{ Pseudo first order model } & \multicolumn{3}{c}{ Pseudo second order model } \\
\hline & $k_{1}$ & $q_{e}$ & $R^{2}$ & $k_{2}$ & $q_{e}$ & $R^{2}$ \\
\cline { 2 - 7 } Cd (II) & 0.032 & 2.630 & 0.893 & 0.104 & 3.906 & 0.994 \\
Cr (VI) & 0.051 & 4.315 & 0.756 & 0.683 & 1.099 & 0.998 \\
\hline
\end{tabular}

\section{Thermodynamic parameters}

Thermodynamic parameters viz. Gibbs free energy $\left(\Delta \mathrm{G}^{\circ}\right)$, the enthalpy $\left(\Delta \mathrm{H}^{\circ}\right)$ and the entropy $\left(\Delta S^{\circ}\right)$ for the adsorption process were obtained using the following eqs. $(9-11)$ :

$$
\begin{gathered}
\Delta G^{\circ}=-R T \ln b \\
\ln b=\frac{\Delta S^{\circ}}{R}-\frac{\Delta H^{\circ}}{R T} \\
\ln \frac{b_{1}}{b_{2}}=\frac{\left[\frac{\Delta H^{\circ}}{R}\left(T_{1}-T_{2}\right)\right]}{T_{1} \times T_{2}}
\end{gathered}
$$

where:

- $R$ is the ideal gas constant $[\mathrm{kJ} / \mathrm{mol} \mathrm{K}]$;

- $T$ is temperature in $\mathrm{K}$;

- $\quad$ and $b$ is the Langmuir constant.

The values of $\Delta \mathrm{G}^{\circ}, \Delta \mathrm{H}^{\circ}, \Delta \mathrm{S}^{\circ}$ were reported in Table 3. Negative value of $\Delta \mathrm{G}^{\circ}$ indicated spontaneous nature of the process for removal of $\mathrm{Cd}$ (II) and $\mathrm{Cr}$ (VI) ions by dried marigold flower. Negative values of $\Delta \mathrm{H}^{\circ}$ suggested exothermic nature of the process. Free energy increased with increase in temperature indicating a decrease in adsorption at higher temperature which also confirmed the exothermic nature of adsorption process (Table 3 ). The negative values of $\Delta \mathrm{S}^{\circ}$ indicated the stability of adsorbed species during adsorption process.

Table 3. Thermodynamic parameters for Cd (II) and Cr (VI) adsorption onto waste marigold

\begin{tabular}{cccccc}
\hline Adsorbates & \multicolumn{3}{c}{$\Delta \mathrm{G}^{\circ}[\mathrm{kJ} / \mathrm{mol}]$} & $\Delta \mathrm{H}^{\circ}[\mathrm{kJ} / \mathrm{mol}]$ & $\Delta \mathrm{S}^{\circ}[\mathrm{kJ} / \mathrm{mol} \mathrm{K}]$ \\
\hline & $30{ }^{\circ} \mathrm{C}$ & $40{ }^{\circ} \mathrm{C}$ & $50{ }^{\circ} \mathrm{C}$ & & \\
\cline { 2 - 4 } $\mathrm{Cd}$ (II) & -10.119 & -10.053 & -9.904 & -12.994 & -0.009 \\
$\mathrm{Cr}$ (VI) & -6.066 & -5.912 & -5.682 & -11.523 & -0.018 \\
\hline
\end{tabular}

\section{Adsorbent regeneration}

In order to test the reusability of heavy metal loaded adsorbent, it was subjected to successive adsorption-desorption cycles. This procedure was tried three times with 100 $\mathrm{mL}$ of $0.1 \mathrm{M} \mathrm{HCl}$ or $0.1 \mathrm{M} \mathrm{NaOH}$ as eluted solution. The percentage adsorption or desorption values were depicted in Table 4 and the results were very promising and 
showed that $0.1 \mathrm{M} \mathrm{HCl}$ solution is suitable eluent for $\mathrm{Cd}$ (II) and $0.1 \mathrm{M} \mathrm{NaOH}$ is suitable eluent for Cr (VI) ions. There was only a slight decrease of heavy metal adsorbed $(5.2 \%$ for Cd (II) and 5.5\% for Cr (VI)), desorbed (4.8\% for Cd (II) and 5.4\% for $\mathrm{Cr}$ (VI)) and a small loss of mass adsorbent (10.2\% for Cd (II) and 9.8\% for $\mathrm{Cr}(\mathrm{VI})$ ). These results showed the ability of dried marigold flower to efficiently adsorb / desorb both Cd (II) and $\mathrm{Cr}(\mathrm{VI})$ ions.

Table 4. Adsorption-desorption cycles of waste marigold for Cd (II) and $\mathrm{Cr}$ (VI) ions

\begin{tabular}{cccccc}
\hline Adsorbates & Cycles & \multicolumn{2}{c}{$0.1 \mathrm{M} \mathrm{HCl}$ solution } & \multicolumn{2}{c}{$0.1 \mathrm{M} \mathrm{NaOH}$ solution } \\
\hline \multirow{6}{*}{ Cd (II) } & & $\begin{array}{c}\text { Adsorption } \\
{[\%]}\end{array}$ & $\begin{array}{c}\text { Desorption } \\
{[\%]}\end{array}$ & $\begin{array}{c}\text { Adsorption } \\
{[\%]}\end{array}$ & $\begin{array}{c}\text { Desorption } \\
{[\%]}\end{array}$ \\
\cline { 3 - 6 } & 1 & 83.1 & 83.9 & 83.1 & 63.1 \\
& 2 & 79.8 & 81.6 & 54.3 & 52.5 \\
& 3 & 77.9 & 79.1 & 46.8 & 41.8 \\
Cr (VI) & 1 & 95.8 & 46.5 & 95.8 & 96.7 \\
& 2 & 41.7 & 39.3 & 93.4 & 94.2 \\
& 3 & 28.6 & 30.4 & 90.3 & 91.3 \\
\hline
\end{tabular}

\section{CONCLUSIONS}

Waste marigold flower was found to be an efficient adsorbent for removal of Cd (II) and $\mathrm{Cr}$ (VI) from aqueous solutions. The $\mathrm{pH}_{\mathrm{zpc}}$ of the adsorbent was found as 4.12. The adsorption of $\mathrm{Cd}$ (II) and $\mathrm{Cr}$ (VI) followed pseudo second order rate expression with boundary layer control as one of the rate determining step. The adsorption isotherm data of $\mathrm{Cd}$ (II) and $\mathrm{Cr}$ (VI) fitted well the Freundlich isotherm. The $0.1 \mathrm{M} \mathrm{HCl}$ and $0.1 \mathrm{M}$ $\mathrm{NaOH}$ solution was shown appropriate eluents for $\mathrm{Cd}$ (II) and $\mathrm{Cr}$ (VI), respectively during desorption operation. The thermodynamic parameters confirmed the exothermic nature of adsorption of both $\mathrm{Cd}$ (II) and $\mathrm{Cr}$ (VI) from aqueous solutions.

\section{ACKNOWLEDGEMENT}

We extend our thanks to Indian Institute of Technology (Banaras Hindu University), Varanasi, India for providing us all the facilities and financial support.

\section{REFERENCES}

1. Argun, M. E. and Dursun, S., A New Approach to Modification of Natural Adsorbent for Heavy Metal Adsorption, Bioresour. Technol., Vol. 99, pp 2516-2527, 2008, http://dx.doi.org/10.1016/j.biortech.2007.04.037

2. Li, X., Tang, Y., Xuana, Z., Liu, Y. and Luoa, F., Study on the Preparation of Orange Peel Cellulose Adsorbents and Biosorption of Cd (II) from Aqueous Solution, Sep.
Purif.
Technol.,
Vol. 55,
$\mathrm{pp}$
69-75,
2007 ,

3. Canet, L., Ilpide, M. and Seta, P., Efficient Facilitated Transport of Lead, Cadmium, Zinc and Silver across a Flat Sheet-supported Liquid Membrane Mediated by a Lasalocid A, Sep. Sci. Technol., Vol, 37, pp 1851-1860, 2002, http://dx.doi.org/10.1081/SS-120003047

4. Reed, B. E. and Matsumoto, M. R., Modeling Cd Adsorption in Single and Binary Adsorbent (PAC) System, J. Environ. Eng. Div. ASCE, Vol. 104, pp 863-878, 1978.

5. Garg, U., Kaur, M. P., Jawa, G. K., Suda, D. amd Garg, V. L., Removal of Cadmium (II) from Aqueous Solutions by Adsorption on Agricultural Waste Biomass, $J$. 


Hazard. Mater., Vol. 154, pp 1149-1157, 2008,

http://dx.doi.org/10.1016/j.jhazmat.2007.11.040

6. Elangovan, R., Philip, L. and Chandraraj, K., Biosorption of Hexavalent and Trivalent Chromium by Palm Flower (Borassus aethiopum), Chem. Eng. J., Vol. 141, pp 99-111, 2008, http://dx.doi.org/10.1016/j.cej.2007.10.026

7. Sun, G. and Shi, W., Sunflower stalks as Adsorbents for the Removal of Metal Ions from Waste Water, Ind. Eng. Chem. Res., Vol. 37, pp 1324-1328, 1998, http://dx.doi.org/10.1021/ie970468j

8. Toles, C. A. and Marshall, W. E., Copper Ion Removal by Almond Shell Carbons and Commercial Carbons: Batch and Column Studies, Sep. Sci. Technol., Vol. 37, pp 2369-238, 2002, http://dx.doi.org/10.1081/SS-120003518

9. Basso, M. C., Cerrella, E. G. and Cukierman, A. L., Lignocellulosic Materials as Potential Biosorbents of Trace Toxic Metals from Wastewater, Ind. Eng. Chem. Res., Vol. 41, pp 3580-3585, 2002, http://dx.doi.org/10.1021/ie020023h

10. Sciban, M., Klasnja, M. and Skrbic, B., Modified Hardwood Saw Dust as Adsorbent of Heavy Metal Ions from Water, Wood Sci. Technol., Vol. 40, pp 217-227, 2006, http://dx.doi.org/10.1007/s00226-005-0061-6

11. Farajzadeh, M. A. and Monji, A. B., Adsorption Characteristics of Wheat Bran towards Heavy Metal Cations, Sep. Sci. Technol., Vol. 38, pp 197-207, 2004, http://dx.doi.org/10.1016/j.seppur.2003.11.005

12. Bhattacharya, A. K., Naiya, T. K., Mondal, S. N. and Das, S. K., Adsorption, Kinetics and Equilibrium Studies on Removal of Cr (VI) from Aqueous Solutions using different Low-cost Adsorbents, Chem. Eng. J., Vol. 137, pp 529-541, 2008.

13. Kapur, M. and Mondal, M. K., Mass Transfer and Related Phenomena for Cr(VI) Adsorption from Aqueous Solutions onto Mangifera Indica Sawdust, Chem. Eng. J., Vol. 218, 138-146, 2013, http://dx.doi.org/10.1016/j.cej.2012.12.054

14. Mondal, M. K., Removal of Pb (II) from Aqueous Solution by Adsorption using Activated Tea Waste, Korean J. Chem. Eng., Vol. 27, pp 144-151, 2010, http://dx.doi.org/10.1007/s11814-009-0304-6

15. Srivastava, V. C., Mall, I. D. and Mishra, I. M., Optimization of Parameters for Adsorption of Metal Ions onto Rice Husk Ash using Taguchi's Experimental Design Methodology, J. Chem. Eng., Vol. 140, pp 136-144, 2008, http://dx.doi.org/10.1016/j.cej.2007.09.030

16. Singh, R. S. and Mondal, M. K., Kinetics, Thermodynamic and Equilibrium Study of Cr (VI) Adsorption from Aqueous Solutions by NCL Coal Dust, Korean J. Chem. Eng., Vol. 29, pp 1782-1787, 2012, http://dx.doi.org/10.1007/s11814-012-0092-2

17. Pegnanelli, F., Mainelli, S., Veglio, F. L. and Toro, L., Heavy Metal Removal by Olive Pomace: Biosorbent Characterisation and Equilibrium Modeling, Chem. Eng. Sci., Vol. 58, pp 4709-4717, 2003, http://dx.doi.org/10.1016/j.ces.2003.08.001

18. Mondal, M. K., Removal of $\mathrm{Pb}$ (II) Ions from Aqueous Solution using activated Tea Waste: Adsorption on a Fixed- bed Column, J. Environ. Manage., Vol. 90, pp 3266-3271, 2009, http://dx.doi.org/10.1016/j.jenvman.2009.05.025 